\title{
Apparent Extirpation of Prey Fish Communities Following the Introduction of Northern Pike (Esox lucius)
}

\author{
Michele E. Nicholson ${ }^{1}$, Michael D. Rennie ${ }^{2,3,4,6}$, and Kenneth H. Mills ${ }^{5}$ \\ ${ }^{1}$ Department of Biology, Queen's University, 116 Barrie Street, Kingston, Ontario K7L 3J9 Canada \\ ${ }^{2}$ International Institute for Sustainable Development, Experimental Lakes Area, 111 Lombard Avenue, Suite 325, Winnipeg, Manitoba \\ R3B 0Y4 Canada \\ ${ }^{3}$ University of Manitoba, Department of Biological Sciences, 212B Bio-Sci Building, 50 Sifton Road, Winnipeg, Manitoba R3B 0T4 \\ Canada \\ ${ }^{4}$ Current address: Department of Biology, Lakehead University, 955 Oliver Road, Thunder Bay, Ontario P7B 5E1 Canada \\ ${ }^{5}$ Fisheries and Oceans Canada (Emeritus), Freshwater Institute, 501 University Crescent, Winnipeg, Manitoba R3T 2N6 Canada \\ ${ }^{6}$ Corresponding author: mrennie@lakeheadu.ca
}

Nicholson, Michele E., Michael D. Rennie, and Kenneth H. Mills. 2015. Apparent extirpation of prey fish communities following the introduction of Northern Pike (Esox lucius). Canadian Field-Naturalist 129(2): 165-173.

We examined the long-term effects on prey fish communities of introducing Northern Pike (Esox lucius), a top predator fish, into small, Boreal Shield lakes lacking natural piscivore populations. During 1987-1994, Northern Pike were introduced into Lakes 110, 221, and 227 in the Experimental Lakes Area in northwestern Ontario, Canada. In Lake 227, prey fish were undetectable three years after the addition of Northern Pike. Although Northern Pike were removed from the lake by 1996, multiple independent visual and trapping surveys have yielded no evidence of any fish in Lake 227 since then. In 1994-1995, 85\% of the Northern Pike were removed from Lake 221. In 2012, despite intensive sampling efforts using baited minnow traps, fyke nets, trap netting, gill netting, angling, and visual observation, no forage fish of any species was observed or caught in Lake 110 or 221 . In all three lakes where Northern Pike were added, prey fish populations were extirpated or too small to detect. In Lake 221, we estimated the current population of Northern Pike to be $49 \pm 37$, a $59 \%$ decrease since 2000 when prey fish were still present. The mean total length and body condition of Northern Pike in Lake 221 had not changed since the prey community collapsed. Our findings suggest that the introduction of Northern Pike into lakes without natural piscivore populations has long-lasting effects on fish community structure, to the detriment of both Northern Pike and prey fish populations.

Key Words: Invasive species; Esocidae; Northern Pike; Esox lucius; biomanipulation; food web manipulation; top predator invasions; top-down effects; Experimental Lakes Area; trophic cascade; fishery management

\section{Introduction}

Over the last few decades, numerous examples have made clear the threat that the introduction of non-indigenous species represents to aquatic ecosystem structure and function. Invasions by piscivorous fish tend to reduce the abundance and diversity of native fish species in lakes, a change that can cause a trophic cascade and have an impact on entire food webs (Ricciardi and MacIsaac 2011). Several instances have been documented of extreme reduction or extirpation of native fish populations in lakes following the introduction of Northern Pike (Esox lucius), a voracious top predator fish species (e.g., DeBates et al. 2003; Byström et al. 2007; Haught and von Hippel 2011). Predation by introduced Northern Pike has been associated with shifts in prey fish community structure from mainly small-bodied, soft-rayed species to deeper-bodied or spiny-rayed species (He and Wright 1992). However, few have reported the whole-scale elimination of the prey fish community (but see Haught and von Hippel 2011), as this is difficult to document (as opposed to measuring the presence of a very small population), and perhaps in part because it is unclear how long it takes a fish community to achieve an equilibrium state following top predator invasion.
At the Experimental Lakes Area (ELA) in northwestern Ontario, Northern Pike were introduced into three small Boreal Shield lakes with native fish communities consisting of only small species (Table 1). In 1987, Northern Pike were stocked in Lake 221 at 6.9 $\mathrm{kg} / \mathrm{ha}$ (Findlay et al. 2005). The forage fish abundance was dramatically reduced within a year and remained low until 1994-95, when $85 \%$ of the Northern Pike were removed by gill net (Findlay et al. 2005). Northern Pike removal continued annually until 2000. By 1997, the lake's Yellow Perch (Perca flavescens) population had returned to pre-Northern Pike abundance and remained relatively constant until 2000, when monitoring ceased. Similarly, Northern Pike were stocked at $26 \mathrm{~kg} / \mathrm{ha}$ in Lake 227 during 1993-1994, and the native cyprinid community was rapidly reduced (Elser $e t$ al. 2000). All of the Northern Pike were removed from the lake in 1996 following intensive gill netting over the summer period, and it has since been fishless (Elser $e t$ al. 2000; M. Rennie, personal communication). Finally, Northern Pike were added to Lake 110 during 19931994 to reach a density of $22.2 \mathrm{~kg} / \mathrm{ha}$ by 1994 (see Elser et al. 1998). By 1995, the abundance of the lake's forage fish had decreased by more than $99 \%$. Unlike Lakes 221 and 227, no Northern Pike were removed from Lake 110. Monitoring of Lake 110 ceased in 1997. The sub-

A contribution towards the cost of this publication has been provided by the Thomas Manning Memorial Fund of the Ottawa Field-Naturalist's Club. 
TABLE 1. Lakes in the Experimental Lakes Area, northwestern Ontario, Canada, where Northern Pike (Esox lucius) populations have been monitored.

\begin{tabular}{lcccrl}
\hline \hline Lake & $\begin{array}{c}\text { Surface } \\
\text { area, ha }\end{array}$ & Latitude, ${ }^{\circ} \mathrm{N}$ & Longitude, ${ }^{\circ} \mathrm{W}$ & $\begin{array}{c}\text { Maximum } \\
\text { depth, } \mathrm{m}\end{array}$ & \multicolumn{1}{c}{ Years sampled } \\
\hline Introduced Northern Pike & & & & & \\
110 & 5.3 & 49.74367261 & 93.82192293 & 13.1 & $1992-1996$ \\
221 & 9.0 & 49.70127842 & 93.72678424 & 5.7 & $1987-2000,2012$ \\
227 & 5.0 & 49.68769463 & 93.68883131 & 10.0 & $1992-2000^{*}$ \\
Native Northern Pike & & & & & \\
191 & 19.4 & 49.57864433 & 93.77932348 & 4.0 & $1994-1995,2001-2003 \dagger$ \\
222 & 16.4 & 49.69642947 & 93.72260758 & 5.8 & $2001-2003,2012$ \\
239 & 54.3 & 49.66265402 & 93.72268920 & 30.4 & $1987-2012$ \\
240 & 44.1 & 49.65452497 & 93.72665578 & 13.1 & $1999-2012$ \\
658 & 8.4 & 49.73362146 & 93.73699463 & 13.0 & $1999-2012$ \\
\hline \hline
\end{tabular}

* Surveys conducted in 1996-2000 revealed no evidence of fish in lake 227. Periodic surveys conducted in 2000-2010 confirmed the ongoing absence of fish, and no fish have been sighted during weekly visits to the lake for eutrophication research.

$\dagger$ Lake 191 was subject to macrophyte removal from 1996 to 1999 . Years included for Lake 191 are only those before macrophyte removal and following recovery of the lake (K. Mills, M. Rennie, unpublished data).

sequent status of the fish communities in Lakes 221 and 110 was unknown until the current study was carried out in summer 2012 .

Given the differences in endpoints reached by the prey fish communities at the cessation of monitoring in each of these Northern Pike-stocked ELA lakes (i.e., prey fish extirpated in Lake 227, low in abundance in Lake 110, and recovered to pre-Northern Pike abundance in Lake 221), we sought to determine the stability of the last known endpoints for prey fish communities in Lakes 110 and 221 by surveying their present-day fish communities, 19-25 years following biomanipulation. We sought to determine whether stocking Northern Pike in these lakes that lack natural piscivore populations would ultimately create a fish community structure comparable to that of nearby, similar lakes with naturally co-existing populations of Northern Pike and prey fish, or if we would find something akin to the observations in ELA Lake 227, where the native forage fish communities had been apparently extirpated.

An inability of predator-naïve forage fish to avoid predatory fish could lead to a post-Northern Pikeintroduction fish community consisting of only Northern Pike and no prey fish or a "pike-only" lake (Patankar et al. 2006). Northern Pike are generally considered to be piscivorous fish that subsist on a diet of prey fish, but pike-only lakes do exist in Canada (e.g., Robinson and Tonn 1989; Beaudoin et al. 1999; Venturelli and Tonn 2006). Pike-only assemblages are thought to occur in small boreal lakes as a result of heavy piscivory by Northern Pike combined with winter hypoxia events that extirpate prey species less tolerant of harsh, low-oxygen conditions (Magnuson and Karlen 1970; Robinson and Tonn 1989). Winterkill has never been observed in ELA lakes, despite very low oxygen levels measured under ice in a number of lake systems that support cyprinids year to year (M. Rennie, personal communication). Northern Pike in pike-only lakes rely on invertivory and cannibalism, and because of low availability of high-quality food sources, tend to have slower growth (Venturelli and Tonn 2006) and potentially smaller mean or maximum body lengths (Huss et al. 2013) than Northern Pike in proximal lakes containing prey fish. We predicted that as prey densities became depleted in Northern Pike-stocked ELA lakes, we would find small populations of Northern Pike, with smaller average body size and poorer body condition than was previously seen, due to a lack of high-quality food sources.

\section{Study Area}

Lakes 110, 221, and 227 are small lakes located at the ELA (Table 1); they are geographically separated and hydrologically distinct from one another $(3-10 \mathrm{~km}$ apart). Lakes 110 and 227 are headwater lakes; Lake 110 flows into a large wetland network before flowing into Lake 625. Lake 227 flows into Lake 305 via a 3-m waterfall. The physical barriers (waterfall, wetlands) make emigration from downstream water bodies to each of these lakes highly unlikely. Lake 221 is a second-order lake, connected upstream to Lake 220 by a small, intermittent, and ephemeral flow of water, and downstream via a large wetland network to Lake 262. As in the other lakes, the nature of these hydrologic connections make movement of fish across water bodies highly unlikely.

\section{Methods}

Survey of prey fish communities

We surveyed the fish communities of Lakes 110 and 221 in July 2012. To assess prey fish populations, we used the methods of Elser et al. (1998, 2000), so that the data would be comparable both temporally and between lakes. In each lake, we deployed 10 minnow traps baited with bread at fixed sites in the littoral (seven traps at $\leq 1 \mathrm{~m}$ depth) and pelagic zones (three traps at 2-12 $\mathrm{m}$ depth), and set a winged fyke net at a fixed 
site perpendicular to shore at $1 \mathrm{~m}$ depth. A small, winged trap net was also deployed at a fixed site in the littoral zone of Lake 221 (1.5 m depth). We sampled daily for five to seven consecutive days. Daily catch per unit effort of small fishes was estimated as the total number of fish captured by all gear divided by the number of sampling devices set.

In addition, fish communities were observed visually by snorkeling in various habitat types of each lake. Over the course of two days, we snorkeled along approximately $95 \%$ of the shorelines, $60-75 \%$ of littoral areas, and $10-30 \%$ of pelagic areas in Lakes 110 and 221. Sightings of Northern Pike, Yellow Perch, and cyprinids were recorded as present (i.e., sighted at least once) or absent (i.e., never sighted).

Nearby Lake 222 was used to evaluate the applied methods (e.g., confirm their ability to detect prey fish when present). Lake 222 has long-standing co-existing populations of Northern Pike, Yellow Perch, and minnows (Blacknose Shiners, Notropis heterolepis) and was the source of many of the Northern Pike added to Lakes 110, 221, and 227 (Elser et al. 1998; Findlay et al. 2005). Methods were identical to those described above, although we were unable to check the traps on the sixth day and assumed that the resultant catch on the seventh day was equally distributed over the twoday period. We snorkeled approximately $10 \%$ of Lake 222 , mostly in littoral areas and stopped after the efficacy of the visual observation method (i.e., ability to detect fish in a lake where they are known to be present) was verified by numerous sightings of Northern Pike, Yellow Perch, and minnows.

Some fish species may be poorly adapted to dealing with Northern Pike predation. To determine the role that initial species assemblage may have played in the outcome of these Northern Pike introductions, we examined prey fish communities that also support Northern Pike among selected ELA lakes equal to or smaller than Lake 222, using reported relative abundance estimates from fishing surveys (Beamish et al. 1976; M. Rennie, P. Blanchfield, and K. Mills, unpublished data). Prey fish in these surveys were collected using a combination of minnow traps, Beamish-style trap nets, and small-mesh gill nets, during various surveys conducted between 1973 and 2012.

\section{Assessment of Northern Pike populations}

Northern Pike populations were assessed using markrecapture methods with angling and short-set experimental gill nets (mesh size 15-50 mm; nets were set for $30 \mathrm{~min}$. to $4 \mathrm{~h}$ ). Captured Northern Pike were weighed, measured, tagged, and released. Handling mortality was recorded but infrequent (typically less than $1 \%$ of all fish captured).

We used the Chapman-modified Lincoln-Petersen method to estimate the population size of Lake 221 in 2012. The modification was applied to compensate for the small sample size, as few fish were captured. The Lincoln-Petersen method uses marking, releasing, and recapturing of animals to estimate the size of a closed population (i.e., no births or immigrants and no deaths or emigrants), assuming equal probability of catching any individual and no loss of markers or marked individuals during the sampling period (Pollock et al. 1990). Population densities in other lakes were estimated using the POPAN method in the program MARK (version 7.2; White and Burnham 1999), based on a fully time-dependent model in each lake. Small samples result in overestimates of population size; however, the Chapman modification can be applied to reduce bias and obtain an approximately unbiased variance (Pollock et al. 1990).

To determine whether stocking densities in these experiments may have been responsible for the response of prey fish communities, standing crops of endemic Northern Pike in ELA lakes were estimated for comparison with those reported from lakes where Northern Pike were introduced and with reports in the scientific literature. Standing crops for each seasonal sampling period in each lake were determined as the mean abundance divided by the mean body mass of Northern Pike. Seasonal standing crops were then averaged within a lake to provide mean standing crop estimates with an associated estimate of error. Northern Pike in these lakes were collected using a variety of methods, including angling, beach seines, and Beamish-style trap nets.

Northern Pike body condition was estimated as an indicator of environmental favorability (e.g., habitat conditions and prey availability) and physiological wellbeing (Blackwell et al. 2000) using Fulton's condition factor $(K)$ :

$$
K=W \times L^{-3} \times 10^{7}
$$

Where $W$ is the wet weight of the fish $(\mathrm{g})$ and $L$ is the fork length of the fish (mm); $10^{7}$ is applied as a scaling constant. We selected a total length range of 400 $500 \mathrm{~mm}$ to compare current and historic conditions and conditions across lakes. Although Fulton's condition factor provides an estimate of body condition based on the relation between a fish's length and weight (Nash et al. 2006), it makes the unrealistic assumption of isometric growth, which is rare in nature (Blackwell et al. 2000), and results in length-related bias when applied across a large size range of fishes (e.g., Rennie and Verdon 2008). Our selection of a specific length range for estimates of $K$ helps reduce this bias. Where data permitted, mean total length $(\mathrm{mm})$ and body condition of Northern Pike were compared between two periods (before 2001 and 2001-2013) and among lakes using two-factor ANOVA. Periods were selected to compare condition and mean length of Northern Pike in Lake 221 up to the end of previous monitoring with contemporary estimates and to permit comparisons with reference lakes. Where period (and the interaction between period and lake) was shown to be non-significant, single-factor ANOVA was used to compare variables among lakes. Significant differences among groups 
were determined using a post-hoc Tukey's HSD (honest significant difference) test with a type I error rate of $\alpha=0.05$. Because this test tends to be conservative in assigning significance, differences with probabilities $<0.1$ are also reported. Log- and square root-transformations were applied to help normalize residuals.

\section{Results}

Prey fish communities

No prey fish were caught or observed by any method during extensive sampling efforts employed in 2012 in either Lake 110 or 221 . Implementing the same methods in Lake 222 resulted in regular daily catches of Yellow Perch and minnows and regular visual observations of both prey fish and Northern Pike while snorkeling and boating (Figure 1).

Prey species that were extirpated from ELA lakes following Northern Pike introduction included Northern Redbelly Dace (Chrosomus eos) in Lakes 110 and 227; Finescale Dace (Phoxinus neogaeus) in Lakes 110 and 227; Pearl Dace (Margariscus margarita) in Lakes 110, 221, and 227; Fathead Minnow (Pimephales promelas) in Lakes 110 and 227; Yellow Perch in Lake 221; Slimy Sculpin (Cottus cognatus) in Lake 110, and White Sucker (Catostomus commersonii) in Lake 110 (Table 2). In ELA lakes of comparable size, Northern Redbelly Dace, Finescale Dace, and Pearl Dace do not co-occur with Northern Pike. In contrast, other lakes of similar size do support populations of Fathead Minnow and Slimy Sculpin and many support Yellow Perch and White Sucker, co-occurring with Northern Pike (Table 2).

\section{Northern Pike populations}

Too few Northern Pike were captured to permit contemporary mark-recapture population estimates in Lake 110. Although only two Northern Pike were caught in Lake 110 during 2012, one was of juvenile size $(<100 \mathrm{~mm})$, which indicated ongoing natural recruitment in the population. The population size of Northern Pike in 2012 for Lake 221 was estimated to be $49 \pm 37$ (Chapman-modified Lincoln-Petersen estimate $\pm 95 \%$ confidence interval), which represents a $59 \%$ decrease in the population since 2000 .

Standing crops of Northern Pike in ELA lakes with native Northern Pike populations ranged from 2.0 to $10.3 \mathrm{~kg} / \mathrm{ha}$ (Table 3). Northern Pike stocking density and current densities in Lake 221 were within this range, whereas stocking densities in Lakes 110 and 227 were twice the highest natural density estimated for ELA lakes (Table 3). The 2012 density of Northern Pike in Lake 221 was less than half that of the initial stocking density (Table 3).

Northern Pike body condition did not vary significantly with time in reference lakes (two-factor ANOVA, $\left.F_{1,1194}=0.13, P>0.05\right)$, nor was there any significant interaction between period and lake $\left(F_{5,1189}=0.40\right.$, $P>0.05)$. However, one-way ANOVA revealed significant differences in Northern Pike body condition

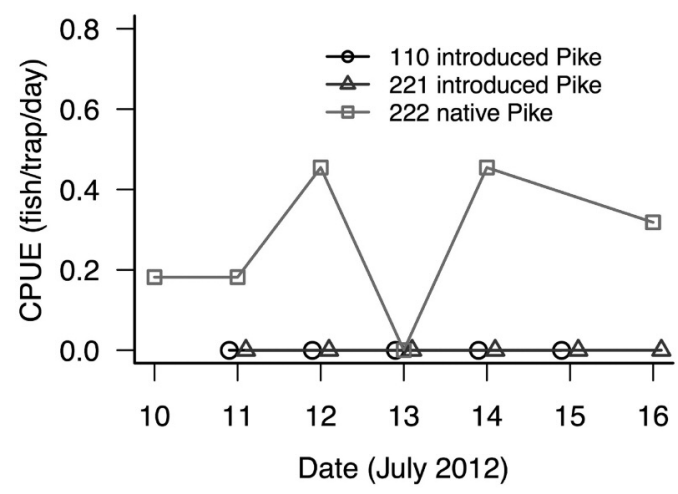

FIGURE 1. Relative prey fish catch per unit effort (CPUE) for Lakes 110, 221, and 222 in the Experimental Lakes Area, northwestern Ontario, using 10 minnow traps and one fyke net in each lake, plus one small trap net in Lake 221. Using these capture methods, no prey fish were detected in Lakes 110 and 221, where Northern Pike (Esox lucius) had been introduced. Offset on $\mathrm{x}$-axis applied to data from lakes 110 and 221 to avoid visual overlap.

among lakes $\left(F_{5,1194}=52.46, P<0.05\right.$; Figure 2$)$. Body condition of the introduced Northern Pike in Lake 221 was similar to that of native Northern Pike in Lakes 239 and 240, but higher than that of native Northern Pike in Lakes 191, 222 (the source of Northern Pike for Lake 221), and 658 (Figure 2).

The mean size of Northern Pike varied by lake and period, (two-factor ANOVA, lake-time interaction, $F_{5,4532}=10.79, P<0.05$; Figure 3$)$. Among our reference lakes, the mean body size of Northern Pike declined significantly in Lakes 191 and 222, and declines observed in Lake 240 were near significant (Figure 3). In contrast, body size was similar between periods in Lake 221 and in two reference lakes (239 and 658; Figure 3).

\section{Discussion}

In the ELA lakes, the introduction of Northern Pike into naïve prey fish communities has consistently, in three independent experiments, resulted in a major initial restructuring of those communities (Elser et al. 1998, 2000; Findlay et al. 2005) and, ultimately, as we have shown here, their apparent extirpation in these lakes. Although the extirpation of prey fish in Lake 227 was known before this study, it was thought that Lake 110 continued to support a remnant prey population and that Lake 221 continued to support Yellow Perch based on surveys conducted during 1995-2000. Our survey, more than a decade later, demonstrated otherwise.

Although the high stocking densities of Northern Pike used in Lakes 110 and 227 might provide an explanation for prey fish extirpation in these experiments, 


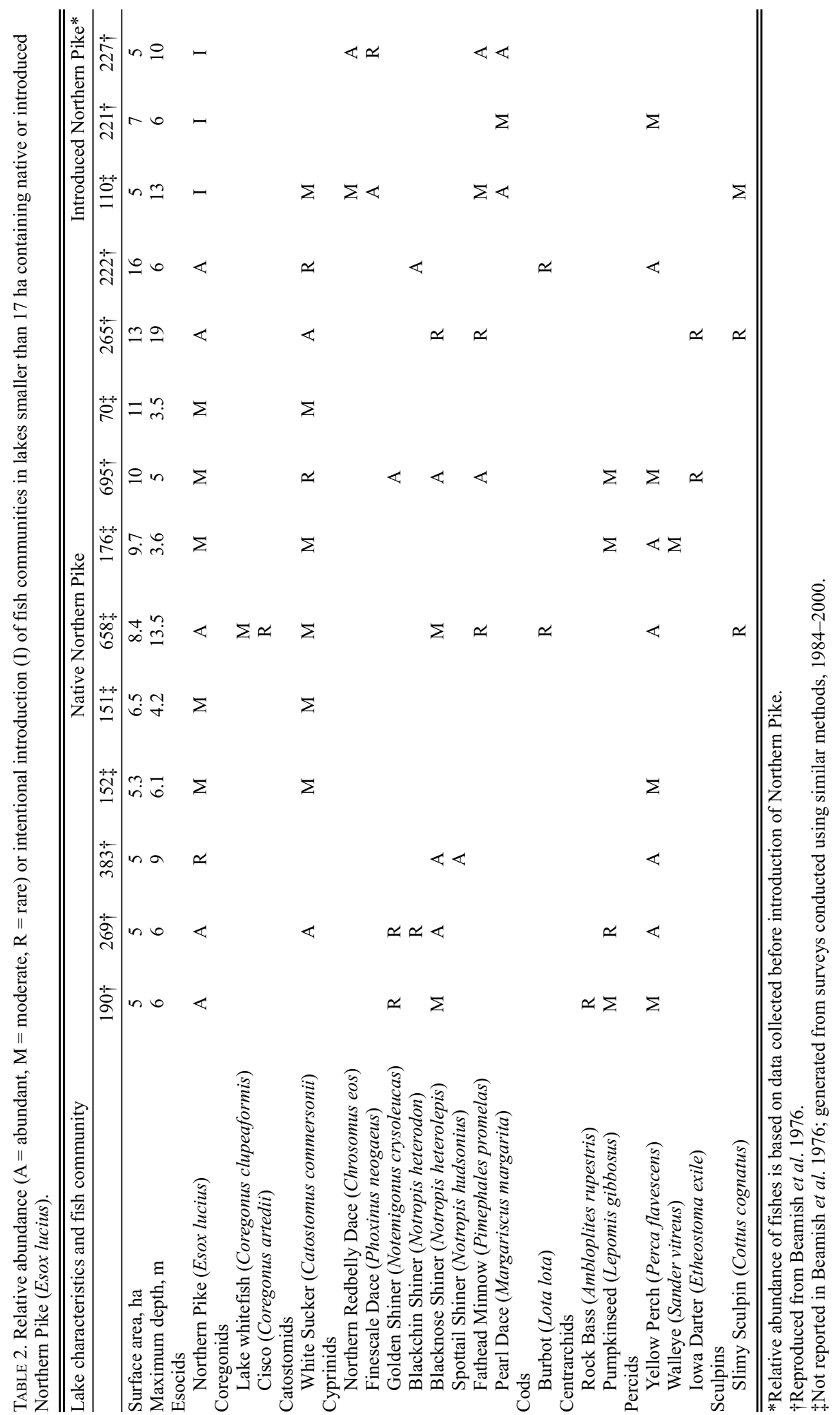


TABLE 3. Standing crop of Northern Pike (Esox lucius) in some lakes of the Experimental Lakes Area, northern Ontario, Canada.

\begin{tabular}{lc}
\hline \hline Lake & $\begin{array}{c}\text { Standing crop, mean } \pm \\
\text { standard deviation, } \mathrm{kg} / \mathrm{ha}{ }^{*}\end{array}$ \\
\hline Introduced Northern Pike & 22.2 \\
110 & 6.9 \\
$221(1987-2000)$ & $2.8 \pm 4.2$ \\
$221(2012)$ & 26.0 \\
227 & \\
Native Northern Pike & $10.3 \pm 2.2$ \\
191 & $8.7 \pm 3.5$ \\
222 & $2.0 \pm 0.8$ \\
239 & $4.5 \pm 1.1$ \\
240 & $8.5 \pm 2.3$ \\
658 & \\
\hline \hline
\end{tabular}

*Means with standard errors are based on multiple seasons of observation. Error for 2012 densities in Lake 221 is based on the error of products (standard deviation in abundance estimates and in mean weight in $\mathrm{kg}$ [Ku 1966]). Values without error are calculated from known stocking densities and individual weights of fish stocked, as reported in the original source: Lake 110, Elser et al. 1998; Lake 221, Findlay et al. 2005; Lake 227, Elser et al. 2000.

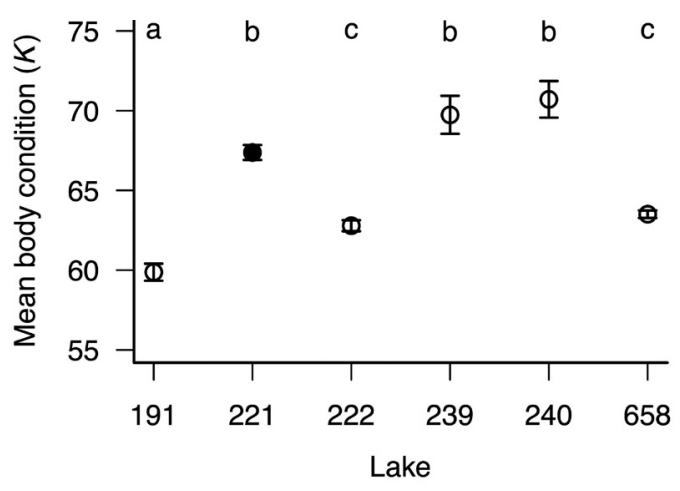

FIGURE 2. Mean body condition (Fulton's condition factor $\times$ $10^{7} \pm$ standard error) of Northern Pike (Esox lucius), 400-500 mm in fork length, from lakes in the Experimental Lakes Area, northwestern Ontario, 19872012. Pike were introduced into Lake 221 (shaded symbol), but were indigenous in the other lakes (open symbols). Years sampled in each lake are reported in Table 1. Means with different letters are significantly different (Tukey's, $P<0.05$ ).

this is likely not the case in Lake 221. In Lake 221, stocking density was within the range of natural standing crops of Northern Pike in similar-sized ELA lakes (Table 3). In Lakes 110 and 227, Northern Pike were added at approximately twice the density of the highest reported standing crop in an ELA lake (Table 3), but comparable to densities of Northern Pike reported elsewhere (Table 4).

Of note is the duration of time required for these lakes to become "pike-only." Although this point ap-

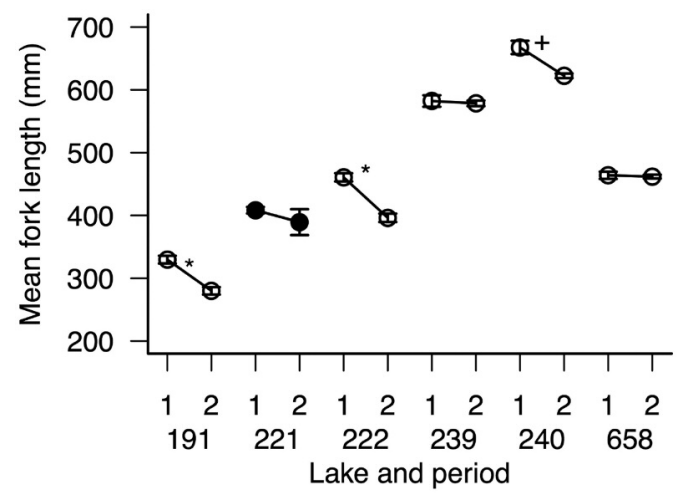

FIGURE 3. Mean fork length ( $\mathrm{mm} \pm$ standard error) of Northern Pike (Esox lucius) in lakes of the Experimental Lakes Area, northwestern Ontario, between 19872000 (period 1) and 2001-2013 (period 2). Pike were introduced into Lake 221 (shaded symbol), but were indigenous in the other lakes (open symbols). Years sampled in each lake are reported in Table $1 .{ }^{*}$ Significant difference between years at $P<0.05$ level; $+P<0.1$.

pears to have been reached only four years after the introduction of Northern Pike into Lake 227, prey fish populations persisted at detectable levels three years after stocking of Northern Pike in Lake 110 (Elser et al. 1998) and 13 years after stocking in Lake 221 (Findlay et al. 2005). Although it is unclear exactly how long it took for these lakes to become devoid of prey fish, other studies suggest that extinction of prey communities takes upward of a decade following Northern Pike invasion (Haught and von Hippel 2011); our data from Lakes 110 and 221 are consistent with this timeline. Pond-based studies have demonstrated that predatornaïve Fathead Minnows are capable of learning appropriate prey responses to Northern Pike within 4-10 days (Brown et al. 1997; Chivers and Smith 1995). However, our work and that of others (Haught and von Hippel 2011) suggest that this learned response may be insufficient to guarantee persistence of naïve prey populations in the long term.

Few other studies report an extirpation of the entire prey fish community following Northern Pike introduction, as was observed in these three ELA lakes. Northern Pike addition 200 years ago resulted in a pike-only community in Lake Myravatn, Norway, until the addition of Yellow Perch in 2006 (Regmi 2012). However, it is also worth noting that none of Lakes 110, 221, or 227 contained endemic piscivore species before Northern Pike introduction, which may make their fish communities particularly ill adapted to respond appropriately to a novel fish predator (Sih et al. 2010).

The extirpation of prey fish from Lakes 110, 221, and 227 was likely due to a combination of both the prey community composition in those lakes and prey naïvety. Cyprinids, in particular, appear to be highly vulnerable to Northern Pike introduction. Small fish 
TABLE 4. Summary of published reports of Northern Pike (Esox lucius) standing crops.

\begin{tabular}{lcccl}
\hline \hline Lake & $\begin{array}{c}\text { Standing } \\
\text { crop, kg/ha }\end{array}$ & $\begin{array}{c}\text { Surface } \\
\text { area, ha }\end{array}$ & $\begin{array}{c}\text { Northern Pike } \\
\text { introduced? }\end{array}$ & Reference \\
\hline Chew Valley Lake & 3.3 & 490 & Y & Ibbotson and Klee 2002 \\
Lake Lyng & $5.2 *$ & 10 & Y & Berg et al. 1997 \\
Slapton Ley & 22.5 & 90 & $\mathrm{~N}$ & Bregazzi and Kennedy 1980 \\
West Long Lake & 22.0 & 25 & $\mathrm{Y}$ & DeBates et al. 2003 \\
Windermere & 9.5 & 1473 & $\mathrm{~N}$ & Kipling and Frost 1970 \\
\hline \hline
\end{tabular}

*Estimate derived from sum of reported annual stocking densities and approximation of mean mass of stocked fishes (assumed $3 \mathrm{~g}$ each).

are typically more susceptible to predation (Tonn et. al. 1992) because of size-selective feeding and gapelimitation in piscivores (Tonn and Paszkowski 1986; Post and Evans 1989), although both body size and morphology contribute to predation risk (He and Kitchell 1990). In Lake 221, Pearl Dace were apparently extirpated within two years of Northern Pike additions, and all four minnow species were eliminated from Lake 227 within three years. Lakes with naturally occurring Northern Pike from similar-sized lakes in the ELA do not appear to support Northern Redbelly Dace (extirpated from Lakes 110 and 227), Finescale Dace (extirpated from Lakes 110 and 227) or Pearl Dace (extirpated from all three lakes where Northern Pike were introduced; Table 2). However, White Sucker (extirpated from Lake 110) naturally co-occurs with Northern Pike in nine of 11 lakes of similar size in the ELA, and Yellow Perch (extirpated from Lake 221) naturally co-occurs with Northern Pike in eight of 11 lakes (Table 2). Fathead Minnow (extirpated from Lake 227) naturally co-occurs with Northern Pike in three of 11 lakes, and other Northern Pike lakes commonly support other minnow species, most notably Blacknose Shiner (six of 11 lakes). This pattern is generally supported by other studies. Among Adirondack lakes ranging in size from 0.1 to 140 ha, Northern Redbelly Dace and Pearl Dace were typically absent from lakes containing Northern Pike and other top piscivores (Findlay et al. 2000). Similarly, Algonquin lakes containing Northern Pike and other top predators were typically negatively associated with Finescale Dace, Northern Redbelly Dace, and Fathead Minnow (Trumpickas et al. 2011). The more frequent co-occurrence of Yellow Perch compared with minnows may be partly due to morphological differences, i.e., the spiny rays of Yellow Perch may afford it greater protection from predators (Willman 2007) than the soft rays of minnows. Habitat use may also play a role, as cyprinids appear especially sensitive to exclusion in the presence of predominantly littoral predators, such as Northern Pike or Smallmouth Bass (Micropterus dolomieu) (Robinson and Tonn 1989; Whittier et al. 1997).

Previously reported biomanipulation studies have described major changes in fish communities due to Northern Pike addition, including extirpations of specific prey fish species. The addition of small Northern Pike to a shallow Polish lake for four years resulted in near failure of recruitment of Roach (Rutilus rutilus) and White Bream (Blicca bjoerkna), due to intense predation on small-bodied fishes, and near-extirpation of Belica (Leucaspius delineatus) (Prejs et al. 1994). Dramatic reductions in Yellow Perch and White Sucker in lakes in the United States have been associated with recruitment failure in these species following Northern Pike addition (Colby et al. 1987; DeBates et al. 2003). Conversely, Yellow Perch and White Sucker increased in abundance following the removal of Northern Pike from Harriet Lake, USA (Colby et al. 1987). Bluegill (Lepomis macrochirus) in West Long Lake, USA responded positively to a reduction in Northern Pike biomass by approximately $50 \%$, but Yellow Perch did not (Jolley et al. 2008).

We do not believe that our inability to detect prey fish in Lakes 110 and 221 following Northern Pike addition is a result of prey behavioural response to predation. Although predator introduction may induce behavioural changes in forage fish (i.e., hiding) that may make them more difficult to catch or observe (Kidd et al. 1999), we employed extensive passive and active sampling methods in these lakes - the same methods that proved effective in our reference Lake 222 (Figure 2), where both Northern Pike and prey fish were present.

Given that many ELA lakes have endemic populations of both Northern Pike and prey fish, the ultimate outcome of the Northern Pike additions in the ELA that we report here may be that, in lakes without natural piscivore populations, prey fish lack effective predator avoidance behaviour and may be unable to adapt quickly enough to avoid being extirpated by novel forms of fish predation. Numerous previous studies have demonstrated that prey naïve to predators may respond differently to predation compared with experienced prey (Sih et al. 2010). Sufficient variation in predator-avoidance behaviours may be lacking among forage fish in lakes without endemic piscivores (which may have been lacking piscivore-related selection pressure since the last glaciation in this region) to generate an appropriate predator response, leaving them ill equipped to deal with introduced predators. Our study suggests that minnows are likely most sensitive to extirpation versus non-cyprinid forage fish species, such as Yellow Perch, as evidenced by the rapid disappearance of minnows in Lakes 110 (Elser et al. 
1998), 221 (Findlay et al. 1994), and 227 (Elser et al. 2000) following Northern Pike introductions. Similar interactions between naïve prey communities and introduced predators may be occurring elsewhere; for instance, as Smallmouth Bass expand their Canadian range northward with a warming North American climate (Sharma et al. 2009).

We found no significant changes in fish condition between periods for Northern Pike in any of our reference lakes or in manipulated Lake 221. Body condition of Northern Pike in Lake 221 (where they were introduced) was relatively high compared with that in reference Lakes 222 and 658, but was comparable with that in reference Lakes 239 and 240. Juvenile Northern Pike can easily survive on invertivory alone, but inadequate access to high-quality food (e.g., forage fish) tends to limit the growth of adult Northern Pike (Venturelli and Tonn 2006). The stability of Northern Pike body condition in the face of a collapse of their prey base can likely be explained by two related factors. First, the biomass of Northern Pike in Lake 221 was less than half the density it was when the prey population was present, indicating a significant reduction in intraspecific competition. Second, Northern Pike are well known to exhibit cannibalism (Venturelli and Tonn 2006 and references therein). Not only does this act to further limit intraspecific competition, but it also provides larger food items that can facilitate more efficient feeding and elevated body condition.

Our study provides insights as to the direction of future research to determine the role of Northern Pike in these small-lake food webs and the cause of prey fish extirpation following Northern Pike introductions. A stable isotope study comparing multiple trophic levels, including fish, zooplankton, and invertebrates before and after Northern Pike introduction (and following prey extirpation) would generate a clearer picture of how pathways of energy transfer have changed in these lakes. Further ongoing efforts to collect Northern Pike from Lakes 110 and 221 will provide an opportunity to compare growth rates under current (preyabsent) conditions versus growth rates when prey were present, as well as versus those in reference lakes, and better ascertain current Northern Pike densities in Lake 110 . On the basis of our findings, we recommend behavioural experiments to examine the susceptibility and behavioural plasticity of small-bodied fish species that are common in lakes both with and without top-predator fish (e.g., Yellow Perch, White Sucker) to better understand the reason for their elimination from the lakes in our study, but common co-occurrence with Northern Pike in many other instances. The potential capability of predatory fishes to drive whole prey fish communities to extirpation, as observed in our studies and suggested by the work of others (e.g., Whittier et al. 1997), underlines the importance of implementing more effective controls on the further dispersal of predatory fish species (e.g., Sharma et al. 2009; Haught and von Hippel 2011) to preserve the diversity of fishes in small lakes lacking native predators.

\section{Acknowledgements}

We thank the following people for assistance with data collection and study design: Mike Paterson, Al Dupuis, Paul Blanchfield, Amy Gilbert, Bailey Rankine, Lindsay Furtado, Brendan Allan, Jon Martin, AJ Chapelsky, David Callaghan, Colin Charles, Matt Guzzo, Dan Abrahamson, and Sandy Chalanchuk. We thank Beth Cheever, Scott Higgins, Rick Baydack, and Paul Venturelli who provided thoughtful comments that helped to improve this manuscript. An earlier draft of this manuscript was improved by the comments of two anonymous reviewers.

\section{Literature Cited}

Beamish, R. J., L. M. Blouw, and G. A. McFarlane. 1976. A fish and chemical study of 109 lakes in the Experimental Lakes Area (ELA), Northwestern Ontario, with appended reports on lake whitefish ageing errors and the Northwestern Ontario baitfish industry. Technical report 607. Fisheries and Marine Service, Research and Development Directorate, Environment Canada.

Beaudoin, C. P., W. M. Tonn, E. E. Prepas, and L. I. Wassenaar. 1999. Individual specialization and trophic adaptability of northern pike (Esox lucius): an isotope and dietary analysis. Oecologia 120: 386-396.

Berg, S., E. Jeppesen, and M. Søndergaard. 1997. Pike (Esox lucius L.) stocking as a biomanipulation tool. 1. Effects on the fish population in Lake Lyng, Denmark. Hydrobiologia 342/343: 311-318.

Blackwell, B. G., M. L. Brown, and D. W. Willis. 2000. Relative weight (Wr) status and current use in fisheries assessment and management. Reviews in Fisheries Science 8: $1-44$.

Bregazzi, P. R., and C. R. Kennedy. 1980. The biology of pike, Esox lucius L., in a southern eutrophic lake. Journal of Fish Biology 17: 91-112.

Brown, G. E., D. P. Chivers, and R. J. F. Smith. 1997. Differential learning rates of chemical versus visual cues of a northern pike by fathead minnows in a natural habitat. Environmental Biology of Fishes 49: 89-96.

Byström, P., J. Karlsson, P. Nilsson, T. Van Kooten, J. Ask, and F. Olofsson. 2007. Substitution of top predators: effects of pike invasion in a subarctic lake. Freshwater Biology 52: $1271-1280$.

Chivers, D. P., and R. J. F. Smith. 1995. Free-living fathead minnows rapidly learn to recognize pike as predators. Journal of Fish Biology 46: 949-954.

Colby, P. J., P. A. Ryan, D. H. Schupp, and S. L. Serns. 1987. Interactions in north-temperate lake fish communities. Canadian Journal of Fisheries and Aquatic Sciences 44 (Suppl. 2): 104-128.

DeBates, T. J., C. P. Paukert, and D. W. Willis. 2003. Fish community responses to the establishment of a piscivore, Northern Pike (Esox lucius), in a Nebraska Sandhill lake. Journal of Freshwater Ecology 18: 353-359.

Elser, J. J., T. H. Chrzanowski, R. W. Sterner, and K. H. Mills. 1998. Stoichiometric constraints on food-web dynamics: a whole-lake experiment on the Canadian Shield. Ecosystems 1: 120-136. 
Elser, J. J., R. W. Sterner, A. E. Galford, T. H. Chrzanowski, D. L. Findlay, K. H. Mills, M. J. Paterson, M. P. Stainton, and D. W. Schindler. 2000. Pelagic C:N:P stoichiometry in a eutrophied lake: responses to a whole-lake food-web manipulation. Ecosystems 3: 293-307.

Findlay, C. S., D. G. Bert, and L. Zheng. 2000. Effect of introduced piscivores on native minnow communities in Adirondack Lakes. Canadian Journal of Fisheries and Aquatic Sciences 57: 570-580.

Findlay, D. L., S. E. M. Kasian, L. L. Hendzel, G. W. Regehr, E. U. Schindler, and J. A. Shearer. 1994. Biomanipulation of Lake 221 in the Experimental Lakes Area (ELA): effects on phytoplankton and nutrients. Canadian Journal of Fisheries and Aquatic Sciences 51: 2794-2807.

Findlay, D. L., M. J. Vanni, M. Paterson, K. H. Mills, S. E. M. Kasian, W. J. Findlay, and A. G. Salki. 2005. Dynamics of a boreal lake ecosystem during a long-term manipulation of top predators. Ecosystems 8: 603-618.

Haught, S., and F. A. von Hippel. 2011. Invasive pike establishment in Cook Inlet Basin lakes, Alaska: diet, native fish abundance and lake environment. Biological Invasions 13: 2103-2114

He, X., and J. F. Kitchell. 1990. Direct and indirect effects of predation on a fish community: a whole-lake experiment. Transactions of the American Fisheries Society 119: 825835.

He, X., and R. A. Wright. 1992. An experimental study of piscivore-planktivore interactions: population and community responses to predation. Canadian Journal of Fisheries and Aquatic Sciences 49: 1176-1183.

Huss, M., L. Persson, J. Borcherding, and L. Heermann. 2013. Timing of the diet shift from zooplankton to macroinvertebrates and size at maturity determine whether normally piscivorous fish can persist in otherwise fishless lakes. Freshwater Biology 58: 1416-1424.

Ibbotson, A., and C. Klee. 2002. Impacts and subsequent control of an introduced predator: the case of pike, Esox lucius, in Chew Valley Lake. Pages 203-216 in Management and Ecology of Lake and Reservoir Fisheries. Edited by I. G. Cowx. Blackwell Publishing, Oxford, UK.

Jolley, J. C., D. W. Willis, T. J. DeBates, and D. D. Graham. 2008. The effects of mechanically reducing Northern Pike density on the sport fish community of West Long Lake, Nebraska, USA. Fisheries Management and Ecology 15: 251-258.

Kidd, K. A., M. J. Paterson, R. H. Hesslein, D. C. G. Muir, and R. E. Hecky. 1999. Effects of northern pike (Esox lucius) additions on pollutant accumulation and food web structure, as determined by $\delta^{13} \mathrm{C}$ and $\delta^{15} \mathrm{~N}$, in a eutrophic and an oligotrophic lake. Canadian Journal of Fisheries and Aquatic Sciences 56: 2193-2202.

Kipling, C., and W. E. Frost. 1970. A study of mortality, population numbers, year class strengths, production and food consumption of pike, Esox lucius L., in Windermere from 1944 to 1962. Journal of Animal Ecology 39: 115157.

Ku, H. H. 1966. Notes on the use of propagation of error formulas. Journal of Research of National Bureau of Standards - C. Engineering and Instrumentation 70C: 263-273.

Magnuson, J. J., and D. J. Karlen. 1970. Visual observation of fish beneath the ice in a winterkill lake. Journal of the Fisheries Research Board of Canada 27: 1059-1068.

Nash, R. D. M., A. H. Valencia, and A. J. Geffen. 2006. The origin of Fulton's condition factor - setting the record straight. Fisheries 31: 236-238.
Patankar, R., F. A. von Hippel, and M. A. Bell. 2006. Extinction of a weakly armoured threespine stickleback ( Gasterosteus aculeatus) population in Prator Lake, Alaska. Ecology of Freshwater Fish 15: 482-487.

Pollock, K. H., J. D. Nichols, C. Brownie, and J. E. Hines. 1990. Statistical inference for capture-recapture experiments. Wildlife Monographs 107: 1-97.

Post, J. R., and D. O. Evans. 1989. Experimental evidence of size-dependent mortality in juvenile yellow perch. Canadian Journal of Zoology 67: 521-523.

Prejs, A., A. Martyniak, S. Borón, P. Hliwa, and P. Koperski. 1994. Food web manipulation in a small, eutrophic Lake Wirbel, Poland: effect of stocking with juvenile pike on planktivorous fish. Hydrobiologia 275/276: 65-70.

Regmi, B. P. 2012. A fish introduction and its impact on the plankton community. Ph.D. thesis, University of Bergen, Bergen, Norway.

Rennie, M. D., and R. Verdon. 2008. Development and evaluation of condition indices for the Lake Whitefish. North American Journal of Fisheries Management 28: 1270-1293.

Ricciardi, A., and H. J. MacIsaac. 2011. Impacts of biological invasions on freshwater ecosystems. Pages 211-224 in Fifty Years of Invasion Ecology: The Legacy of Charles Elton. Edited by D. M. Richardson. Wiley-Blackwell, Chichester, United Kingdom.

Robinson, C. L. K., and W. M. Tonn. 1989. Influence of environmental factors and piscivory in structuring fish assemblages of small Alberta lakes. Canadian Journal of Fisheries and Aquatic Sciences 46: 81-89.

Sharma, S., D. A. Jackson, and C. K. Minns. 2009. Quantifying the effects of climate change and invasive species on native species. Ecography 32: 517-525.

Sih, A., D. I. Bolnick, B. Luttbeg, J. L. Orrock, S. D. Peacor, L. M. Pintor, E. Preisser, J. S. Rehage, and J. R. Vonesh. 2010. Predator-prey naïveté, antipredator behavior, and the ecology of predator invasions. Oikos 119: 610 621.

Tonn, W. M., and C. A. Paszkowski. 1986. Size-limited predation, winterkill, and the organization of Umbra-Perca fish assemblages. Canadian Journal of Fisheries and Aquatic Sciences 43: 194-202.

Tonn, W. M., C. A. Paszkowski, and I. Holopainen. 1992. Piscivory and recruitment: mechanisms structuring prey populations in small lakes. Ecology 73: 951-958.

Trumpickas, J., N. E. Mandrak, and A. Ricciardi. 2011. Nearshore fish assemblages associated with introduced predatory fishes in lakes. Aquatic Conservation: Marine and Freshwater Ecosystems 21: 338-347.

Venturelli, P. A., and W. M. Tonn. 2006. Diet and growth of Northern Pike in the absence of prey fishes: initial consequences for persisting in disturbance-prone lakes. Transactions of the American Fisheries Society 135: 1512-1522.

White, G. C., and K. P. Burnham. 1999. Program MARK: survival estimation from populations of marked animals. Bird Study 46 (Suppl.): 120-138.

Whittier, T. R., D. B. Halliwell, and S. G. Paulsen. 1997. Cyprinid distributions in Northeast U.S.A. lakes: evidence of regional-scale minnow biodiversity losses. Canadian Journal of Fisheries and Aquatic Sciences 54: 1593-1607.

Willman, S. 2007. Testing the role of spines as predatory defense. Journal of Shellfish Research 26: 261-266.

Received 28 October 2014

Accepted 5 May 2015 